\title{
THE RELIABILITY OF VIBRATION BASED MOBILE PHONE IN DETECTING PERIPHERAL NEUROPATHY IN PATIENT WITH DIABETIC FOOT ULCERS
}

\author{
Muh. Jasmin $^{1,2}$, Saldy Yusuf ${ }^{2 *}$, Fitria Amrullah ${ }^{2,3}$, Fitrawati Arifuddin ${ }^{2,4}$ \\ ${ }^{1}$ Program Studi Keperawatan, STIKES Karya Kesehatan, Kendari, Indonesia \\ ${ }^{2}$ Fakultas Keperawatan, Universitas Hasanuddin, Makassar, Indonesia \\ ${ }^{3}$ Rumah Sakit Umum Daerah Labuang Baji Makassar \\ ${ }^{4}$ Fakultas Kedokteran dan Ilmu Kesehatan, UIN Alauddin Makassar \\ Corresponding Author: saldy_yusuf@yahoo.com
}

\begin{abstract}
The aim of this study was to evaluate the reliability of mobile phone vibrations in detecting peripheral neuropathy in diabetic foot wound patients between the nurse and the patient's family. The design of this study was a pilot study with a cross sectional study approach. The study was conducted on 37 respondents in four wound care clinics in Makassar City and its surroundings. The instrument used is a mobile phone vibration using the vibrations-test application. Interater reliability analysis test used cohen's kappa test. The results showed that $67.6 \%$ of the patients did not feel the vibrations of the mobile phones performed by the nurses, while $70.3 \%$ of the patients did not feel the vibrations of the cellphones carried out by the family. Interrater reliability examination of diabetic feet using a mobile phone vibration shows an almost perfect agreement, namely $(\mathrm{k}=0.973)$. The reliability of mobile phone vibrations using the vibrations-test application is quantitatively reliable. Thus, mobile phone vibrations can be used as an alternative screening tool to detect neuropathy in Diabetes Mellitus patients in the community.
\end{abstract}

Keywords: Interrater reliability, mobile phone vibration, peripheral neuropathy, diabetic foot ulcer. 


\section{PENDAHULUAN}

Salah satu komplikasi dari penyakit DM adalah neuropati. Komplikasi utama DM di Indonesia adalah neuropati (13\%-78\%) (Soewondo, Ferrario, and Tahapary 2013). Neuropati dapat meningkatkan kejadian Luka Kaki Diabetik (LKD) (Matheus et al., 2013). Penelitian sebelumnya menunjukkan prevalensi LKD di Indonesia adalah 12\% (Yusuf et al., 2016). Tingginya persentase neuropati di komunitas memungkinkan terjadi peningkatan LKD ekstremitas bawah (Wukich et al. 2016). LKD dapat dihindari dengan cara melakukan skrining awal di komunitas bagi pasien DM (Milne 2013). Dengan demikian, perlu adanya strategi dalam mendeteksi neuropati pada penderita DM.

Deteksi neuropati pasien DM dapat menggunakan monofilament test, namun, masih memiliki sensitivitas yang rendah (Wang et al. 2017), butuh keahlian khusus, relatif mahal, dan alat tersebut belum tersedia di komunitas (Halamar, Syam, \& Yusuf, 2017). Berdasarkan hal tersebut, saat ini ada beberapa pendekatan untuk mengevaluasi neuropati menggunakan sentuhan ringan, salah satunya adalah vibrasi handphone.

Vibrasi handphone sudah bisa digunakan untuk mendeteksi neuropati. Penelitian sebelumnya menunjukkan bahwa vibrasi handphone memiliki akurasi yang baik untuk pemeriksaan neuropati yaitu 0.88 (May et al. 2016). Teknologi smartphone yang sedang menjadi tren saat ini adalah adanya sistem operasi berbasis android (Pratiwi and Restanti 2018). Hasil penelitian menunjukkan bahwa mayoritas (95\%) responden melaporkan memiliki handphone dan sebagian besar (88\%) memiliki smartphone (Shields et al. 2018). Selain itu pengguna handphone saat ini khususnya di Indonesia semakin meningkat (Shields et al. 2018). Berdasarkan hal tersebut, handphone berpotensi digunakan dalam praktek pemeriksaan Kesehatan, termasuk neuropati.

Deteksi neuropati perifer menggunakan vibrasi telah dievaluasi menggunakan alat seperti VibraTip (Willits et al. 2015), PeriVib (Jacobs et al. 2018), Neurotip, garpu tala $128 \mathrm{~Hz}$ (Bracewell et al. 2012), dan Neuropad (Ponirakis et al. 2014). Saat ini telah dilaporkan bahwa vibrasi handphone dapat digunakan untuk mendeteksi neuropati (May et al. 2016). Namun belum digunakan di klinis komunitas termasuk pada pasien luka kaki diabetes, dan kelaurga. Pemeriksaan kesehatan pada pasien DM dipengaruhi oleh pengetahuan keluarga (Rahmawati, Ratna, and Ekwantini 2017). Keluarga sangat berperan penting dalam meningkatkan perilaku dan kemandirian pemeriksaan dan perawatan kaki pada pasien DM (Ernawati et al. 2020; Sari, Haroen, and Nursiswati 2016). Oleh karena itu tujuan penelitian ini untuk mengevaluasi reliabilitas vibrasi handphone dalam mendeteksi neuropati perifer pada pasien LKD antara perawat dan keluarga pasien.

\section{METODE}

Desain penelitian ini adalah Pilot Study dengan pendekatan cross sectional study di empat klinik perawatan luka di Kota Makassar dan sekitarnya. Target populasi dalam penelitian ini adalah pasien luka kaki diabetes. Tekhnik sampling yang digunakan adalah purposive sampling dengan kriteria inklusi:pasien DFU, tidak ada Riwayat amputasi, dan dapat berkomunikasi dengan baik.

Variabel independent dalam penelitian ini adalah vibrasi handphone menggunakan aplikasi android, 
sedangkan variable dependent adanya sensasi yang dirasakan oleh partisipan (yes-no). Aplikasi yang digunakan adalah vibrations-test. Aplikasi ini mengaktifkan motor didalam ponsel dalam pola dan frekuensi yang konsisten untuk menghilangkan variabel potensial dalam perangkat lunak handphone.

Untuk interrater reliability akan dilakukan pemeriksaan neuropati antar perawat dengan keluarga. Pengambilan data akan dilakukan oleh perawat dan keluarga secara langsung dengan waktu yang hampir bersamaan berdasarkan kriteria inklusi pada empat klinik luka di Kota Makassar. Masing-masing klinik terdiri dari 1 perawat yang memenuhi kriteria inklusi untuk mendeteksi neuropati perifer pada penderita DM menggunakan vibrasi handphone. Setiap observer akan melakukan skrining pada pasien DM yang sama menggunakan vibrasi handphone dengan waktu yang hampir bersamaan (Observer perawat akan diberikan kesempatan pertama untuk menskrining neuropati perifer menggunakan vibrasi handphone dan selanjutnya kesempatan diberikan kepada observer keluarga). Konfirmasi neuropati dilakukan melalui pemeriksaan monofilament test 10 gram.

Interater reliability dengan melakukan uji cohen's kappa untuk menilai kesepakatan antara dua orang observer dalam menilai pemeriksaan neuropati perifer menggunakan vibrasi handphone (Donner and Rotondi 2010; Seeber et al. 2018). Izin etik diperoleh di komisi etik FKM UNHAS dengan nomor rekomendasi persetujuan etik 8359/UN4.14.1/TP/02.02/2020

\section{HASIL}

\section{Statistik Demografi Pasien}

Tabel 1.

Data Demografi Pasien Luka Kaki Diabetes, $n=37$ responden

\begin{tabular}{lcc}
\hline Data Demografi & Frekuensi (n) & Persentase (\%) \\
\hline Jenis Kelamin & & 37.8 \\
Laki - Laki & 14 & 62.2 \\
Perempuan & 23 & 10.828 \\
Usia (mean, SD) & 55.46 & \\
Suku & & 32.4 \\
Bugis & 12 & 54.2 \\
Makassar & 20 & 2.7 \\
Bugis Makassar & 1 & 2.7 \\
Tator & 1 & 5.4 \\
Jawa & 2 & 2.7 \\
Lain - lain & 1 & 16.2 \\
Pekerjaan & & 24.3 \\
PNS & 6 & 2.7 \\
Wiraswasta/ Pegawai Swasta & 9 & 43.2 \\
Petani & 1 & 13.5 \\
IRT & 16 & \\
Pensiunan & 5 & 94.6 \\
Agama & & 5.4 \\
Islam & 35 & 21.6 \\
Kristen & 2 & 5.4 \\
Pendidikan & & \\
SD & 2 & \\
SMP & & \\
\hline
\end{tabular}




\begin{tabular}{|c|c|c|}
\hline SMA & 12 & 32.4 \\
\hline Perguruan Tinggi & 15 & 40.5 \\
\hline \multicolumn{3}{|l|}{ Status Perkawinan } \\
\hline Kawin & 35 & 94.6 \\
\hline Tidak kawin & 1 & 2.7 \\
\hline Janda & 1 & 2.7 \\
\hline Total & 37 & 100 \\
\hline
\end{tabular}

Pada hasil penelitian didapatkan bahwa jumlah responden terbanyak adalah perempuan yakni 23 (62.2\%) responden dengan rata-rata usia 55,46. Selain itu, mayoritas responden berasal dari suku Makassar (54.2\%) dan suku Bugis (32.4\%) dengan status perkerjaan terbanyak sebagai IRT (43.2\%) dan wiraswasta/ pegawai swasta (24.3\%). Mayoritas responden juga menganut agama Islam (94.6\%) dengan status perkawinan, $94.6 \%$ telah menikah dan tingkat pendidikan, $40.5 \%$ menyelesaikan perguruan tinggi dan $32.4 \%$ menyelesaikan tingkat SMA (Tabel 1).

Tabel 2.

Data Demografi Keluarga Pasien Luka Kaki Diabetes, n=37 responden

Data Demografi $\quad$ Frekuensi (n)
Persentase (\%)

\begin{tabular}{l}
\hline Jenis Kelamin \\
Laki - Laki \\
Perempuan \\
Usia (mean, SD) \\
Suku (n : 36) \\
Bugis \\
Makassar \\
Bugis Makassar \\
Tator \\
Jawa \\
Lain - lain \\
Pekerjaan (n: 36) \\
IRT \\
PNS \\
Wiraswasta/ Pegawai Swasta \\
Mahasiswa \\
Tidak Bekerja \\
Agama \\
Islam \\
Kristen \\
Pendidikan \\
SMP \\
SMA \\
Perguruan Tinggi \\
Hubungan \\
Suami \\
Istri \\
Anak \\
Keluarga Lain \\
Total \\
\end{tabular}

$\begin{array}{cc}15 & 40.5 \\ 22 & 62.2 \\ 36.66 & 13.029\end{array}$

\section{7}

21

19.4

58.3

8.3

2.8

8.3

2.8

25

$10 \quad 27.8$

925

$\begin{array}{ll}7 & 19.4\end{array}$

12.8

$35 \quad 94.6$

$2 \quad 5.4$

$2 \quad 5.4$

$8 \quad 21.6$

$27 \quad 73$

$5 \quad 13.5$

$6 \quad 16.2$

$20 \quad 54.1$

$6 \quad 16.2$

$37 \quad 100$




\section{Statistik Demografi Keluarga}

Pada hasil penelitian didapatkan bahwa jumlah responden terbanyak adalah perempuan $(62.2 \%)$ responden dengan rata-rata usia 36.6. Selain itu, mayoritas responden berasal dari suku Makassar (58.3\%) dengan status perkerjaan terbanyak sebagai PNS (27.8\%). Mayoritas responden juga menganut agama Islam (94.6\%) dengan tingkat pendidikan terbanyak menyelesaikan perguruan tinggi (73\%). Mayoritas responden merupakan anak $(54.1 \%)$ dari pasien yang menderita penyakit DM (Tabel 2).

Tabel 3.

Status DM Pasien Luka Kaki Diabetes, n=37 responden

\begin{tabular}{lcc}
\hline \multicolumn{1}{c}{ Status DM } & Frekuensi (n) & Persentase (\%) \\
\hline Gula Darah Sewaktu (mean, SD) (n : 24) & 216.38 & 68.449 \\
Gula Darah Puasa (mean, SD) (n: 9) & 204.33 & 76.363 \\
Terapi DM (n: 34) & 22 & 64.7 \\
$\quad$ Oral & 4 & 11.8 \\
Insulin & 5 & 14.7 \\
Oral dan Insulin & 3 & 8.8 \\
Tidak ada terapi DM & & \\
Lama DM (n : 35) & 2 & 5.7 \\
<1 Tahun & 15 & 42.9 \\
1-5 Tahun & 13 & 37.1 \\
6-10 Tahun & 5 & 14.3 \\
11-15 Tahun & & \\
Penyebab DM (n: 36) & 8 & 22.2 \\
Keturunan & 3 & 8.3 \\
Pola Hidup & 7 & 19.4 \\
Adanya luka & 17 & 47.2 \\
Check Up & 1 & 2.8 \\
Kehamilan & 37 & 100 \\
Total & & \\
\hline
\end{tabular}

penyakit DM karena faktor keturunan

\section{Status DM}

Pada hasil penelitian didapatkan bahwa rata-rata nilai gula darah sewaktu responden (n: 24) yakni $216.38 \mathrm{mg} / \mathrm{dl}$ dan nilai gula darah puasa (n: 9) yakni $204.33 \mathrm{mg} / \mathrm{dl}$. Selain itu, mayoritas responden telah mengidap DM dalam rentang waktu 15 tahun yakni sebesar $42.9 \%$ dan rentang waktu 11-15 tahun sebesar $37.1 \%$. dari penelitian juga didapatkan data jika mayoritas responden mengetahui mengidap penyakit DM setelah melakukan check up (47.2\%) beberapa reseponden juga memiliki
(22.2\%) (Tabel 3).

\section{Pemeriksaan Kaki}

Tabel 4. Pemeriksaan Kaki Pasien, n=37 responden

\begin{tabular}{lcc}
\hline $\begin{array}{l}\text { Pemeriksaan } \\
\text { Kaki }\end{array}$ & $\begin{array}{c}\text { Frekuen } \\
\text { si (n) }\end{array}$ & $\begin{array}{c}\text { Persentas } \\
\text { e (\%) }\end{array}$ \\
\hline Monofilament & & \\
Test & & \\
Dorsal Hallux & & \\
$\quad$ Present & 12 & 32.4 \\
$\quad$ Absent & 25 & 67.6 \\
$1^{\text {st }}$ Metatarsal & & \\
$\quad$ Present & 13 & 35.1 \\
$\quad$ Absent & 24 & 64.9 \\
\hline
\end{tabular}




\begin{tabular}{lll}
\hline $3^{\text {rd }}$ Metatarsal & & \\
Present & 14 & 37.8 \\
Absent & 23 & 62.2 \\
5 & & \\
Metatarsal & 11 & 29.7 \\
Present & 26 & 70.3 \\
Absent & & \\
Vibrasi Handpho & & \\
$\quad$ ne & & \\
Perawat
\end{tabular}

\begin{tabular}{ccc}
\hline Present & 12 & 32.4 \\
Absent & 25 & 67.6 \\
Keluarga & & \\
Present & 11 & 29.7 \\
Absent & 26 & 70.3 \\
Total & 37 & 100 \\
\hline
\end{tabular}

Tabel 5. Uji Reliabilitas pada Pasien Luka Kaki Diabetes, n=37 responden

\begin{tabular}{|c|c|c|c|c|c|}
\hline \multirow{2}{*}{ Perawat } & \multicolumn{2}{|c|}{ Keluarga } & \multirow{2}{*}{ Total } & \multirow{2}{*}{ Kappa (k) } & \multirow{2}{*}{$p$ value } \\
\hline & Present $(n, \%)$ & Present $(n, \%)$ & & & \\
\hline Present $(n, \%)$ & 11 (29.7) & $1(2.7)$ & $12(32.4)$ & & \\
\hline Absent $(n, \%)$ & $0(0.0)$ & $25(67.6)$ & $25(67.6)$ & 0.937 & $<0.001$ \\
\hline Total & $11(29.7)$ & $26(70.3)$ & $37(100)$ & & \\
\hline
\end{tabular}

\section{Uji Reliabilitas}

Hasil penelitian didapatkan pada pemeriksaan monofilament pada titik Dorsal Hallux sebanyak $67.6 \%$ responden tidak merasakan sensasi rangsangan dan $32.4 \%$ merasakan sensasi rangsangan. Pada titik $1^{\text {st }}$ Metatarsal sebanyak $64.9 \%$ responden tidak merasakan sensasi rangsangan sedangkan $35.1 \%$ merasakan sensasi rangsangan. Pada titik $3^{\text {st }}$ Metatarsal sebanyak $62.2 \%$ responden tidak merasakan sensasi rangsangan dan $37.8 \%$ merasakan sensasi rangsangan. Pada titik $5^{\text {st }}$ Metatarsal sebanyak $70.3 \%$ responden tidak merasakan sensasi rangsangan dan sebanyak $29.7 \%$ responden masih merasakan sensasi rangsangan (Tabel 4). Pada pemeriksaan dengan vibrasi handphone sebanyak $67.6 \%$ partisipan tidak merasakan vibrasi handphone dan $32.4 \%$ merasakan vibrasi handphone yang dilakukan oleh perawat, sedangkan sebanyak $70.3 \%$ tidak merasakan vibrasi handphone dan 29.7 merasakan vibrasi handphone yang dilakukan oleh keluarga. Hasil interrater reliability pemeriksaan kaki diabetes menggunakan vibrasi handphone menunjukkan kesepakatan hampir sempurnah yaitu ( $\mathrm{k}=0.973)$ (Tabel 5).

\section{DISKUSI}

\section{Interrater reliability}

Dalam penelitian ini peneliti melakukan interrater reliability untuk menilai kehandalan instrumen. Penelitian ini terdapat 4 pasang observer dengan masing-masing 2 observer dari Klinik Griya Afiat, ETN Centre, ISAM Cahaya, dan Rumah Luka Gowa. Setiap observer melakukan pemeriksaan neuropati menggunakan vibrasi handphone dengan total 37 pasien. Interrater reliability merupakan tes yang mencakup penentuan secara kualitatif tingkat kesepakatan antara dua atau lebih pengamat (Heale and Twycross 2015). Penelitian sebelumnya menunjukkan bahwa untuk menilai interrater reliability menggunakan 2 observer untuk menilai 20 partisipan (Holmes 
et al. 2020). Pengambilan minimal 10 kali oleh 2 atau lebih observer untuk melakukan uji reliabilitas diagnostik atau alat pengkajian baru (Gankande et al. 2014). Apabila observer semakin sering melakukan penilaian suatu prosedur akan memungkinkan semakin baik hasil kesepakatan hasil yang diperoleh.

Hasil analisis interrater reliability menunjukkan ada kesepakatan diantara penilai pada instrument dan waktu yang sama. Hasil analisis nilai interrater reliability memiliki nilai kappa yang baik. Hal ini dipengaruhi oleh lama pekerjaan observer dan tanggung jawab observer sebagai perawat luka. Penelitian sebelumnya menunjukkan bahwa terdapat kesepakatan yang tinggi ketika menggunakan observer berpengalaman (Duncan, Donovan, and Sajjadi 2019). Pengukuran statistik yang digunakan untuk mengukur interrater reliability yaitu dengan Cohen's Kappa untuk 2 penilai (McHugh 2012). Kesepakatan antara dua atau lebih observer dalam suatu pengukuran yang dilakukan dibuat dalam persentasi agreement yang diterima jika berkisar diatas $70 \%$ (Taherdoost, 2016). Dengan demikian untuk menilai interrater reliability minimal observer yaitu 2 orang.

\section{Implikasi dalam Praktik Keperawatan}

Melakukan uji validitas dan reliabilitas pada suatu alat diagnostik baru merupakan hal yang sangat penting untuk mendapatkan hasil yang valid, akurat, dan dapat dipercaya. Sebuah metode dikatakan valid jika alat yang digunakan tidak memiliki perbedaan dengan alat golden standart. Sedangkan dikatakan reliabel atau andal jika para penilai mencapai hasil yang relatif sama dalam setiap pengukuran. Kesalahan atau kekurangan dari sebuah metode dalam meneggakan diagnosis dapat menyebabkan kesalahan interpretasi yang pada akhirnya akan salah menentukan intervensi keperawatan. Sebaliknya, apabila sebuah metode diagnosis telah valid, reliabel, dan bersifat universal untuk digunakan pada setiap tingkatan kompetensi akan sangat membantu dalam penetapan diagnosis. Vibrasi handphone menggunakan aplikasi vibrations-test adalah alat portabel yang dapat digunakan untuk mendeteksi neuropati pada pasien DM. Saat ini sudah terdapat beberapa alat atau cara mendeteksi neuropati seperti monofilament $10 \mathrm{~g}$, garputala $128 \mathrm{~Hz}$, vibratip yang belum tersedia di komunitas dan IppT yang masih bersifat subjektif. Sehingga, saat ini terdapat aplikasi vibrations-test yang mudah digunakan menggunakan handphone android dan sangat potensial untuk direkomendasikan sebagai metode alternatif dalam mendeteksi neuropati pada pasien DM, namun perlu memperhatikan potensi bias pada saat melakukan pemeriksaan.

\section{Keterbatasan Penelitian}

$$
\text { Peneliti tidak dapat }
$$
menghindari potensi bias yang ditemukan pada saat pasien DM memberikan jawaban hasil pemeriksaan peneliti dan teknik pemeriksaan dari observer saat memberikan tekanan handphone pada titik pemeriksaan pada pasien sehingga dapat mempengaruhi hasil. Hasil pemeriksaan beberapa pasien menggunakan vibrasi handphone dilakukan berulang-ulang.

\section{KESIMPULAN}


Reliabilitas vibrasi handphone menggunakan aplikasi vibrations-test secara kuantitatif reliabel. Pada uji interrater reliability ditemukan hasil kesepakatan hampir sempurnah. Dengan demikian vibrasi handphone menggunakan aplikasi vibrations-test dapat digunakan sebagai alat skrining alternatif untuk mendeteksi neuropati pada pasien DM di komunitas.

\section{DAFTAR PUSTAKA}

Bracewell, N., F. Game, W. Jeffcoate, and B. E. Scammell. 2012. "Short Report: Care Delivery Clinical Evaluation of a New Device in the Assessment of Peripheral Sensory Neuropathy in Diabetes." Diabetic Medicine 1553-55.

Donner, Allan, and Michael A. Rotondi. 2010. "Sample Size Requirements for Interval Estimation of the Kappa Statistic for Interobserver Agreement Studies with a Binary Outcome and Multiple Raters." International Journal of Biostatistics 6(1).

Duncan, E. Susan, Neila J. Donovan, and Sayed Ahmad Sajjadi. 2019. "Clinical Assessment of Characteristics of Apraxia of Speech in Primary Progressive Aphasia." American Journal of Speech-Language Pathology 29(1):485-97.

Ernawati, Dwi, Siti Harri, Setia Ningrum, and Nuh Huda. 2020. "The Family Independence In Doing Foot Care At Kedungdoro Primary Health Care Surabaya." Jurnal Keperawatan Malang 5(1):10-16.

Gankande, T. U., J. M. Duke, P. L. Danielsen, H. M. DeJong, F. M. Wood, and H. J. Wallace. 2014. "Reliability of Scar Assessments Performed with an
Integrated Skin Testing Device - The DermaLab Combo®." Burns 40(8):1521-29.

Halamar, Halbina Famung, Yuliana Syam, and Saldy Yusuf. 2017. "Tes Sederhana Deteksi Neuropati Pada Pasien Diabetes Mellitus Tipe 2: Studi Literatur." Jurnal Keperawatan Muhammadiyah 2(2):21-25.

Heale, Roberta, and Alison Twycross. 2015. "Validity and Reliability in Quantitative Studies." Evidence-Based Nursing 18(3):1-3.

Holmes, Carlee, Emma Fredrickson, Kim Brock, and Prue Morgan. 2020. "The Intra- and Inter-Rater Reliability of the Goldsmith Indices of Body Symmetry in Non-Ambulant Adults with Cerebral Palsy." Disability and Rehabilitation 0(0):1-7.

Jacobs, Peter G., Peter Hanaway, Joseph Leitschuh, John Condon, Clara Mosquera-lopez, Carolyn Guidarelli, and Kerri Winters-stone. 2018. "Design and Evaluation of a Portable Smart - Phone Based Peripheral Neuropathy Test Platform." IEEE 3898-3901.

Matheus, Alessandra Saldanha De Mattos, Lucianne Righeti Monteiro Tannus, Roberta Arnoldi Cobas, Catia C. Sousa Palma, Carlos Antonio Negrato, and Marilia De Brito Gomes. 2013. "Impact of Diabetes on Cardiovascular Disease : An Update." 2013(Cvd).

May, Jonathan David, Matthew William, John Morris, and Frcs Tr. 2016. "Foot and Ankle Surgery Mobile Phone Generated Vibrations Used to Detect Diabetic Peripheral Neuropathy." 
Foot and Ankle Surgery 8-11.

McHugh, Mary L. 2012. "Lessons in Biostatistics Interrater Reliability: The Kappa Statistic." Biochemica Medica 22(3):276-82.

Milne, Jeanette. 2013. "Diabetic Foot Ulcer Management in the Community." Wounds UK 9(1):10-13.

O'Brien, Todd, and Joseph Karem. 2014. "An Initial Evaluation of a Proof-ofConcept 128-Hz Electronic Tuning Fork in the Detection of Peripheral Neuropathy." Journal of the American Podiatric Medical Association 104(2):134-40.

Ponirakis, G., I. N. Petropoulos, H. Fadavi, U. Alam, 0. Asghar, A. Marshall, M. Tavakoli, and R. A. Malik. 2014. "The Diagnostic Accuracy of Neuropad $\AA$ for Assessing Large and Small Fibre Diabetic Neuropathy." Diabetic Medicine 31(12):1673-80.

Pratiwi, Intan Gumilang, and Dian Aby Restanti. 2018. "Penerapan Aplikasi Berbasis Android \&quot;Status Gizi Balita\&quot; Terhadap Pengetahuan Ibu Dalam Pemantauan Status Gizi Anak Usia 12-24 Tahun." Jurnal Kebidanan Akademi Kebidanan Jember 2(1):8-14.

Rahmawati, Agustina, Wahyu Ratna, and Rosa Delima Ekwantini. 2017. "Gambaran Pengetahuan Keluarga Dengan Diabetes Melitus Tentang Pencegahan Komplikasi Diabetes Melitus Di Wilayah Kerja Puskesmas Sentolo 2." 1-10.

Sari, Windani Mambang Citra, Hartiah Haroen, and Nursiswati Nursiswati. 2016. "Pengaruh Program Edukasi
Perawatan Kaki Berbasis Keluarga Terhadap Perilaku Perawatan Kaki Pada Pasien Diabetes Melitus Tipe 2." Jurnal Keperawatan Padjadjaran v4(n3):305-15.

Seeber, Gesine H., Christoph Thalhamer, Julia Hahne, and Omer Matthijs. 2018. "Validation, Intrarater and Interrater Reliability Study of the LateralAnterior Drawer Test for Detecting Posterior Cruciate Ligament Ruptures: Study Protocol of a Prospective Controlled SingleBlinded Cross-Sectional Study." BMJ Open 8(5):1-5.

Shields, Wendy C., Elise Omaki, Eileen M. McDonald, Ruth Rosenberg, Mary Aitken, Martha Wood Stevens, and Andrea C. Gielen. 2018. "Cell Phone and Computer Use among Parents Visiting an Urban Pediatric Emergency Department." Pediatric Emergency Care 34(12):878-82.

Soewondo, Pradana, Alessandra Ferrario, and Dicky Levenus Tahapary. 2013. "Challenges in Diabetes Management in Indonesia: A Literature Review." 1-17.

Taherdoost, Hamed. 2016. "Validity and Reliability of the Research Instrument; How to Test the Validation of a Questionnaire/Survey in a Research." International Journal of Academic Research in Management (IJARM) 5(3):28-36.

Takahara, Mitsuyoshi, Yuko Fujiwara, Fumie Sakamoto, Naoto Katakami, Taka Aki Matsuoka, Hideaki Kaneto, and Iichiro Shimomura. 2014. "Assessment of Vibratory Sensation with a Tuning Fork at Different Sites in Japanese Patients with Diabetes 
Mellitus." Journal of Diabetes Investigation 5(1):90-93.

Wang, Fengyi, Jiaqi Zhang, Jiadan Yu, Shaxin Liu, Rengang Zhang, Xichao $\mathrm{Ma}$, Yonghong Yang, and $\mathrm{Pu}$ Wang. 2017. "Diagnostic Accuracy of Monofilament Tests for Detecting Diabetic Peripheral Review Article Diagnostic Accuracy of Monofilament Tests for Detecting Diabetic Peripheral Neuropathy: A Systematic Review and Meta-Analysis." (October):1-12.

Willits, Iain, Helen Cole, Roseanne Jones, Paul Dimmock, Mick Arber, Joyce Craig, and Andrew Sims. 2015. "VibraTip TM for Testing Vibration Perception to Detect Diabetic Peripheral Neuropathy: A NICE Medical Technology Guidance." Applied Health Economics and Health Policy 13(4):315-24.

Wukich, Dane K., David Sadoskas, Nicholas J. Vaudreuil, and Mitchell Fourman. 2016. "Comparison of Diabetic Charcot Patients With and Without Foot Wounds."

Yusuf, Saldy, Mayumi Okuwa, Muhammad Irwan, Saipullah Rassa, Baharia Laitung, Abdul Thalib, Sukmawati Kasim, Hiromi Sanada, Toshio Nakatani, and Junko Sugama. 2016. "Prevalence and Risk Factor of Diabetic Foot Ulcers in a Regional Hospital , Eastern Indonesia." Open Journal of Nursing 6(February):1-10. 